\title{
Peran UKM dalam Perekonomian: Studi Kasus Kota Yogyakarta
}

\author{
Jaka Sriyana
}

The article below traces and investigates the real sector of economy case study at Yogyakarta. The real sector of economy has an important role in term of Indonesian economy especially in preparing vocation. These real sectors of economy need regulating by government to increase them, in paticular in overcoming their obstacles. The regulation should include all field of real sectors, for instance bank access, economical situation. Thus, the goal of this is to support dan increase their competitive advantages and to sustain their business.

Kata kunci: sektor informal, penyerapan tenaga kerja

Kawa awasan perkotaan di Indonesia, seperti juga perkotaan di dunia ketiga, banyak dijumpai berkembangnya industri kecil sebagai akibat tidak mampunya pemerintah mengatasi masalah pengangguran dan kemiskinan. Beberapa kegiatan industri kecil bahkan masuk dalam sektor informal. Namun keberadaan mereka belum mendapat perhatian serius dari pemerintah. Pada umumnya pemerintah daerah sebagai pengelola kota masih banyak memikirkan sektor formal yang lebih mudah dikontrol. Padahal sektor industri kecil (dan menengah) memiliki kontribusi yang nyata bagi pengatasan masalah pengangguran dan masalah perekonomian kawasan perkotaan. ILO melaporkan bahwa $60 \%$ buruh di kotakota negara berkembang diserap oleh sektor informal dan kegiatan pada usaha kecil dan menengah (UKM). Dilaporkan juga bahwa peran sektor UKM sangat penting karena mampu menciptakan pasar-pasar, mengembangkan perdagangan, mengelola sumber alam, mengurangi kemiskinan, membuka lapangan kerja, membangun masyarakat dan menghidupi keluarga mereka tanpa kontrol dan fasilitas dari pihak pemerintah daerah yang memadai (ILO, 1991-dan Reddy et.al,', 2002). Di Indonesia, sektor UKM bahkan menjadi tumpuan kehidupan yang semakin besar sejak terjadinya krisis ekonomi yang dimulai pada tahun 1997 (Sarosa, 2000).

Dalam pembahasan mengenai sektor usaha kecil tentunya tidak terlepas dengan permasalahan urbanisasi dan migrasi ataupun pengangguran. Kenyataan baru tersebut adalah terjadinya arus urbanisasi dan migrasi yang melanda negara-negara di dunia secara besar-besaran. Adarlya perpindahan atau mobilisasi penduduk dại pedesaan ke perkotaan tersebut secara berkait mau tidak mau adalah karena akibat strategi pembangunan yang dijalankan. Terlepas dari terdapatnya implikasi baik 
positif maupun negatif yang ditimbulkan, temyata keberadaan urbanisasi dan migrasi menjadikan suatu kasus tersendiri yang mutlak memerlukan pengelolaan dan perencanaan dari sisi kebijakan ekonomi (economic policy).

Permasalahan urbanisasi dan migrași dianggap sebagai kekuatan yang terus menerus memperburuk masalah pengangguran di perkotaan yang disebabkan oleh ketidakseimbangan struktural dan ekonomi antara daerah pedesan dan perkotaan, dimana lokasi perkotaan terus diberi insentif untuk mengembangkan kegiatan ekonominya, sementara lokasi pedesaan justru makin lama makin dijauhkan dari kemungkinankemungkinan untuk mengakselerasi tingkat kemajuannya. Dengan begitu, terjadinya proses urbanisasi dan migrasi tersebut pada hakekatnya merupakan refleksi perbedaan pertumbuhan dan ketidakmerataan fasilitas pembangunan antara satu daerah dengan daerah lain, dan untuk itu terdapat argumentasi bahwa model pembangunan ekonomi yang dilakukan selama ini tidak mengarahkan adanya suatu hasil atau pemerataan sejajar antar wilayah di daerah yang sama; dalam hal ini antara wilayah pedesaan dan perkotaan. Pada tabel berikut ini dapat kita lihat sebarapa besar peranan migrasi desa ke kota sebagai sumber pertumbuhan penduduk perkotaan di beberapa negara berkembang.

Secara lebih lanjut, Michael P. Todaro menganalisa ketidak-seimbangan struktural desa dan kota dari dua sudut.Pertama, dari sisi penawaran (supply). Karena perpindahan penduduk tersebut berlangsung terusmenerus maka akan terjadi arus urbanisasi secara berlebihan sehingga menaikkan tingkat pertambahan periduduk perkotaan. Pada akhirnya, kehadiran mereka cenderung untuk menambah jumlah penawaran tenaga kerja di perkotaan, sementara persediaan tenaga kerja yang sangat berarti di pedesaan sangat menipis.Kedua, dari sisi permintaan (demand). Disini penciptaan tenaga kerja di perkotaan lebih sulit dan mahal daripada penciptaan-lapangan pekerjaan di pedesaan, karena adanya kebutuhan terhadap input-input komplementer yang sangat banyak bagi kebanyakan pekerjaan di sektor industri. Maksudnya, untuk membuka kesempatan kerja di sektor industri dibutuhkan lebih banyak biaya tambahan dibandingkan di sektor pertanian tradisional, sehingga mengakibatkan sedikitnya jumlah kesempatan kerja yang dapat dibuka di sektor industri perkotaan tersebut.

Dikatakan pula oleh Michael P. Todaro dan Jerry Stilkind, bahwa saat sekarang kota-kota telah tumbuh dengan terlalu pesat dengan ditandai oleh tiga hal. Pertama, jumlah pengangguran dan setengah menganggur yang besar dan semakin meningkat. Kedua, proporsi tenaga kerja yang bekerja pada sektor industri di kota hampir tidak dapat bertambah dan malahan mungkin berkurang. Ketiga, jumlah penduduk dan tingkat pertumbuhannya sudah begitu pesat sehingga pemerintah tidak mampu memberikan pelayanan kesehatan, perumahan, dan transportasi yang memadai. Ketiga hal tersebut menjadi ciri khas dari setiap kota (metropolitan) sebagai akibat dari pola industrialisasi yang dijalankan secara serempak dan dengan design yang sangat mirip.

Dengan latar belakang seperti itulah, lahir fenomena perkembangan UKM di negara-negara berkembang pada umunya. Mereka yang melakukan urbanisasi dan tidak dapat tertampung di sektor formal terpaksa harus menciptakan lapagan kerja sendiri. Mereka yang menganggur di 
perkotaan tersebut untuk kembali lagi ke desa harus berpikir dua kali, karena di desa mereka menjumpai kondisi yang tidak menguntungkan, seperti sumber daya alam yang terbatas, upah rendah, tidak memiliki tanah dan lain sebagainya. Semakin metropolis sebuah daerah, maka semakin terbuka ruang bagi pengusaha untuk memasuki dan memenuhi sudut-sudut kota tersebut. Secara lebih mengerucut, keberadaan mereka biasanya tersebar di pusat-pusat kegiatan ekonomi yang memberikan peluang permintaan terhadap produk yang mereka tawarkan.

\section{Peranan UKM dalam Perekonomiañ}

Perkambangan sektor usaha kecil dañ menengah hingga saat ini jumlahnya telah menggelembung sedemikian besar bahkan hampir menyamai jumlah mereka yang bekerja di sektor formal lainnya. Di banyak negara-negara miskin dan berkembang, kontribusi-yang bisa diberikan oleh pelaku usaha kecil mencapai $30 \%-60 \%$ dari selunuh penduduk perkotaan. Sedangkan di wilayah Jawa jumlah pelaku sektor ini berkisar antara $37 \%$ sampai $43 \%$, sementara di luar Jawa lebih banyak lagi berkisar antara $40 \%-55 \%$. Dengan begitu, saat ini tidak bisa dikatakan lagi bahwa sektor usaha kecil dan menengah cuma sebagai tempat penampungan sementara bagi para pekerja yang belum bisa masuk ke sektor formal lainnya, tetapi keberadaannya justru sebagai motor pertumbuhan aktivitas ekonomi (perkotaan) karena jumlah penyerapan tenaga kerjanya yang demikian besar (sama dengan jumlah tenaga kerja di sektor formal).

Di banyak negara di dunia, pembangunan dan pertumbuhan usaha kecil dan menengah (UKM) merupakan salah satu motor penggerak pertumbuhan ekonomi. Dari penelitian Tambunan (2003) disebutkan bahwa salah satu karakteristik dari dinamika dan kinerja ekonomi yang baik dengan laju pertumbuhan yang tinggi di negara-negara Asia Timur dan Tenggara yang dikenal dengan Newly Industrializing Countires (NICs) seperti Korea Selatan, Singapura, dan Taiwan adalah kinerja UKM mereka yang sangat efisien, produktif dan memiliki tingkat daya saing yang tinggi. UKM di negara-negara tersebut sangat responsif terhadap kebijakan-kebjjakan pemerintahannya dalam pembangunan sektor swasta dan peningkatan pertumbuhan ekonomi yang berorientasi ekspor. Di negara-negara sedang berkembang, UKM juga sangat penting peranannya. Di India, misalnya, UKM-nya menyumbang $32 \%$ dari nilai total ekspor, dan $40 \%$ dari nilai output dari sektor industri manufaktur dari negara tersebut. Di beberapa negara di kawasan Afrika, perkembangan dan pertumbuhan UKM, termasuk usaha mikro, sekarang diakui sangat penting untuk menaikkan output agregat dan kesempatan kerja..

Masih menurut Tambunan (2000), disebutkan bahwa di indonesia, di lihat dari jumlah unit usahanya yang sangat banyak yang terdapat di semua sektor ekonomi dan kontribusinya yang besar terhadap kesempatan kerja dan pendapatan, khususnya di daerah pedesaan dan bagi keluarga berpendapatan rendah, tidak dapat diingkari betapa pentingnya UKM bagi pembangunan ekonomi nasional. Selain itu, selama ini kelompok usaha tersebut juga berperan sebagai suatu motor penggerak yang sangat krusial bagi pembangunan ekonomi dan komunitas lokal. Sekarang, UKM memiliki peranan baru yang lebih penting lagi yakni sebagai salah satu faktor utama pendorong perkembangan dan pertumbuhan eksor non-migas dan sebagai industri pendukung yang membuat komponen-komponen dan spare parts untuk industri besar (IB) lewat keterkaitan produksi 
misalnya dalam bentuk subcontracting. Bukti di NICs menunjukkan bahwa bukan hanya usaha besar (UB) saja, tetapi UKM juga bisa berperan penting di dalam pertumbuhan ekspor dan bisa bersaing di pasar domestik terhadap barang-barang impor maupun di pasar global. sehingga mampu menyediakan lebih banyak kesempatan kerja baru dengan berbagai cara. Tahun 2000 , lebih dari 66 juta orang bekerja di UK, atau sekitar $99,44 \%$ dari jumlah kesempatan kerja; suatu kenaikan sebsar $12,04 \%$ atau sekitar 7,2 juta orang dibandingkan tahun 1999.

Tabel 1 Jumlah Unit UK dan Penyediaan Kesempatan Kerja Menurut Sektor, 1997-2000

\begin{tabular}{|c|c|c|c|c|c|c|}
\hline Sektor & \multicolumn{4}{|c|}{ Tahun } & \multirow{2}{*}{$\begin{array}{l}\text { Pertumbuh } \\
\text { an (\%), } \\
1997-1998\end{array}$} & \multirow{2}{*}{$\begin{array}{c}\text { Rata-rata } \\
\text { pertumbuha } \\
\text { n (\%), } \\
1998-2000 \\
\end{array}$} \\
\hline & 1997 & 1998 & 1999 & 2000 & & \\
\hline $\begin{array}{l}\text { Jumlah Usaha } \\
\text { Kecil } \\
\text { Jumlah Perusahaan } \\
\text { Nasional }\end{array}$ & $\begin{array}{r}39.704 .661 \\
(99,84) \\
39.767 .207\end{array}$ & $\begin{array}{r}36.761 .689 \\
(99,85)\end{array}$ & $\begin{array}{r}37.804 .536 \\
(99,86)\end{array}$ & $\begin{array}{r}38.985 .072 \\
(99,85)\end{array}$ & $-7,4$ & 3,0 \\
\hline $\begin{array}{l}\text { Jumlah Pekerja di } \\
\text { Usaha Kecil } \\
\text { Jumlah pekerja di } \\
\text { semua perusahaan }\end{array}$ & 57.482 .688 & 47.341 .962 & 59.646 .722 & 66.827 .890 & $-17,6$ & 18,8 \\
\hline
\end{tabular}

Sumber: Diolah dari Tambunan (2003).

Keterangan angka dalam kurung adalah \% dari perusahaan nasional

Perkembangan UKM di Indonesia sangatlah pesat dari tahun ke tahun. Walaupun demikian dnegan adanya krisis ekonomi telah mengakibatkan banyaknya usaha yang merugi, bahkan menutup usahanya. Namun beberapa tahun berikutnya telah terjadi perkembangan yang signifikan, baik dalam jumlah unit, penyediaan lapangan kerja maupun jumlah output yang dihasilkan. UKM di Indonesia memiliki perana sangat penting terutama dalam hal penyediaan kesempatan kerja. Pendapat ini didasarkan pada berbagai kenyataan dan fenomena yang menunjukkan bahwa kelompok usaha ini mempekerjakan lebih banyak orang dibandingkan unit-unit usaha lain. Mereka diharapkan bisa tetap menciptakan dan mengembangkan usahanya sampai pada skala optimalnya

\section{Berbagai Kajian Tentang UKM}

Dikatakan oleh Michael P. Todaro (2000), bahwa saat sekarang kota-kota telah tumbuh dengan terlalu pesat dengan ditandai oleh tiga hal. Pertama, jumlah pengangguran dan setengah menganggur yang besar dan semakin meningkat. Kedua, proporsi tenaga kerja yang bekerja pada sektor industri di kota hampir tidak dapat bertambah dan malahan mungkin berkurang. Ketiga, jumlah penduduk dan tingkat pertumbuhannya sudah begitu pesat sehingga pemerintah tidak mampu memberikan pelayanan kesehatan, perumahan, dan transportasi yang memadai. Ketiga hal tersebut menjadi ciri khas dari setiap kota yang mengalami pertumbuhan kegiatan ekonomi dengan cepat. Studi yang dilakukan oleh Michae! P. Todaro (2000), dikatakan bahwa sektor 
informal pada umumnya ditandai oleh beberapa karakteristik seperti sangat bervariasinya bidang kegiatan produksi barang dan jasa, berskala kecil, unit-unit produksinya dimiliki secara perorangan atau keluarga, banyak menggunakan tenaga kerja (padat karya), dan teknologi yang dipakai relatif sederhana. Para pekerja yang menciptakan sendiri lapangan kerjanya di sektor UKM biasanya tidak memiliki pendidikan formal. Pada umumnya mereka tidak mempunyai ketrampilan khusus dan sangat kekurangan modal kerja. Oleh sebab itu, produktivitasnya dan pendapatan mereka cenderung lebih rendah daripada kegiatankegiatan bisnis lainnya. Selain itu, mereka yang berada di sektor tersebut juga tidak memiliki jaminan keselamatan kerja dan fasilitas-fasilitas kesejahteraan seperti yang dinikmati rekan-rekan mereka di sektor lain.

Bagaimanapun keberadaan UKM sangat perlu dikembangkan lebih lanjut dan dibina dengan baik. Adapun alasanalasannya menurut Todaro (2000), adalah sebagai berikut :

1. Sebagai akibat dari rendahnya intensitas penggunaan kapital, hanya sebagian kecil saja dari kapital yang diperlukan untuk mempekerjakan pekerja.

2. Menyediakan kesempatan kerja dalam jumlah yang cukup besar, khususnya bagi negara berkembang

3. Pada umumnya membutuhkan tenaga yang tidak memiliki ketrampilan atau cukup hanya setengah terampil saja yang penawarannya semakin meningkat dan penawaran tersebut mustahil akan diserap oleh sektor industri besar yang sifat permintaannya lebih banyak membutuhkan tingkat yang berketerampilan.

4. Sektor UKM mungkin akan dapat menggunakan teknologi tepat guna dan memanfaatkan sumber daya setempat yang memungkinkan alokasi sumber daya dapat dilaksanakan secara lebih efisien.

Studi yang dilakukan oleh International Labour Organization (ILO) seperti dikemukakan dalam Sethuraman (1993), dijelaskan bahwa aktivitas-aktivitas UKM tidak terbatas pada pekerjaan-pekerjaan tertentu, tetapi bahkan juga meliputi berbagai aktivitas ekonomi yang antara lain ditandai dengan: mudah untuk dimasuki, bersandar pada sumberdaya lokal, usaha milik sendiri, opersinya dalam skala kecil, padat karya dan teknologinya bersifat adaptif, ketrampilan dapat diperoleh di luar sistem sekolah formal, dan tidak terkena langsung oleh regulasi dan pasarnya bersifat kompetitif. Studi yang dilakukan ILO ini menyebutkan sektor UKM punya ciri: ukuran usaha kecil, kepemilikan keluarga, intensif tenaga kerja, status usaha individu, tanpa promosi, dan tidak ada hambatan masuk.

Menurut Chris Manning, dkk (1991) sektor UKM adalah bagian dari sistem ekonomi kota dan desa yang belum mendapatkan bantuan ekonomi dari pemerintah atau belum mampu menggunakan bantuan yang telah disediakan atau telah menerima bantuan tetapi belum sanggup dikembangkan. Sektor UKM di Indonesia, umumnya mempunyai ciri-ciri sebagai berikut: Kegiatan usaha tidak terorganisasikan secara baik, karena - timbulnya unit usahā tidak mempergunakan fasilitas/kelembagaan yang tersedia, tidak nmempunyai izin usaha, pola kegiatan usaha tidak teratur baik dalam arti lokasi maupun jam kerja, pada umunya kebijakan pemerintah untuk membantu golongan ekonomi lemah tidak sampai ke sektor ini. Pada umumnya UKM di Indonesia masih dihadapkan pada berbagai permasalahan yeng menghambat kegiatan usahnya. 
Berbagai hambatan etrsebut melipúti kesulitan pemasaran; keterbatasan finansial, keterbatasan SDM berkualitas, masalah bahan baku, keterbatasan teknologi, infrastruktur pendukung dan rendahnya komitmen pemerintah.

\section{Berbagai Temuan Kajian Survei UKM di Yogyakarta}

Survei yang dlakukan di Jogjakarta ini meliputi tiga besar kelompok industri kecil dan menengah, yaitu kelompok industri bidang mebel, kerajinan kulit, dan industri pengolahan makanan yang berjumlah 61 unit usaha. Dari hasil survei diperoleh data-data yang dipaparkan pada tabel 2 - tabel 12 berikut.

Sarana dan prasarana yang meliputi jalan raya, listrik, air, telekomunikasi merupakan faktor penting yang mendukung usaha. Dari hasil survei menunjukkan bahwa hanya sekitar $15 \%$ dari total sampel yang mengatakan bahwa kualitas sarana dan prasarana baik, sedangkan $60 \%$ mengatakan cukup. Ini menunjukkan bahwa sarana baru merupakan faktor yang mampu mendukung iklim usaha dalam arti minimalis, belum mampu menjadi daya dukung yang optimal. mereka. Ini berarti bahwa perlu adanya regulasi dari pemerintah untuk menyediakan area-area yang diperuntukkan bagi sentrasentra pengembangan usaha (spasial) sehingga akan menjamin pula kelangsungan usaha mereka. Kebijakan tata ruang merupakan faktor yang sangat penting. Dari sini dapat dilihat pula bahwa usaha-usha kecilyang ada di Yogyakarta berbaur dengan perumahan untuk kediaman tempat tinggal.

Fasilitas lain berupa dana juga merupakan faktor yang tidak mendukung usaha. Sekitar $56 \%$ pengusaha mengatakan bahwa tingkat bunga mahal. Mereka berharap ada kebijakan dari pemerintah untuk memberikan subsidi tingkat bunga sehingga tidak membebani mereka. Dilihat dari persepsi mereka menunjukkan bahawa cost of capita/masih mahal. Ini mendukung adanya high cost economy di Yogyakarta. Dilihat dari beban biaya yang harus dikeiuarkan, maka porsi yang terbesar ada pada mahalnya bahan baku yang mencapai $32 \%$, sedangkan tenaga kerja dan bahan bakar masingmasing hanya 23 dan 21 persen.

Dilihat dari jumlah konsưmen yang membeli produk mereka, rata-rata lebih dari 50 orang mencapai lebih dari $50 \%$ dari total sampel. Ini merupakan angka yang tinggi

Tabel 2. Kelompok Usaha

\begin{tabular}{|l|c|c|}
\hline \multicolumn{1}{|c|}{ Jenis Usaha } & Jumlah & \% \\
\hline Kerajinan Kayu, Meubel. & 42 & 68,85 \\
\hline Kerajinan Kulit & 10 & 16,39 \\
\hline Pengolah Makanan & 9 & 14,75 \\
\hline
\end{tabular}

Adapaun fasilitas fisik yang sangat diperlukan oleh sebagian besar pengusaha adalah lahan usaha dan bangunan usaha untuk meningkatkan kegiatan usaha bagi sebuah industri kecil. Tetapi prestasi ini tidak mendukung adanya jaminan kelangsungan usaha mereka. Hanya sekitar $25 \%$ dari mereka yang mengatakan bahwa 
Topik: Keterpaduan Sektor Formal dan Informal Perkotaan

usaha mereka masih berjalan lebih dari 10 tahun. Sekitar $58 \%$ dari mereka mengatakan bahwa usaha mereka akan berhenti pada kurun waktu kurang dari 10 tahun. Bahkan ada sekitar $24 \%$ dari mereka akan terancam usahanya pada kurun waktu kurang dari 5 tahun. Ini berkorelasi pula dengan tingkat persaingan usaha. Sekitar $75 \%$ mënyatakan bahwa persaingan usaha cukup ketat.

Penyediaan lapangan kerja merupakan masalahutamabagipeningkatankesejahteraan masyarakat. UKM memiliki pernan penting dalam penyediaan lapangan kerja. Hasil survei di Yogyakarta ini menunjukkan bahwa sebagian besar usaha kecil hanya

Tabel 3. Persepsi Pengusaha tentang Kualitas Sarana dan Prasarana

\begin{tabular}{|l|c|c|}
\hline Penilaian & Jumlah & Persentase \\
\hline Sangat Baik & 1 & 1,63 \\
\hline Baik & 9 & 14,75 \\
\hline Cukup & 37 & 60,65 \\
\hline Kurang & 11 & 18,03 \\
\hline Sangat Kurang & 3 & 4,91 \\
\hline & $\mathbf{6 1}$ & 100 \\
\hline
\end{tabular}

Tabel 4. Fasilitas yang Dibutuhkan

\begin{tabular}{|l|c|c|}
\hline & Jumlah & \% \\
\hline Lahan Usaha & 26 & 42,62 \\
\hline Bangunan & 13 & 21,31 \\
\hline Kepastian Usaha & 18 & 29,50 \\
\hline Lainya & 4 & 6,55 \\
\hline Total & $\mathbf{6 1}$ & $\mathbf{1 0 0}$ \\
\hline
\end{tabular}

Tabel 5. Komponen Biaya Operasional Usaha

\begin{tabular}{|l|c|c|}
\hline \multicolumn{1}{|c|}{ Item } & Jumlah & \% \\
\hline Tenaga Kerja & 14 & 22,95 \\
\hline Bahan Baku & 32 & 52,45 \\
\hline Bahan Bakar & 13 & 21,31 \\
\hline Lainnya & 2 & 3,27 \\
\hline & 61 & \\
\hline
\end{tabular}


Geliat UKM dalam Perekonomiaan Lokal: Studi Kasus di Jogjakarta; Jaka Sriyana

Tabel 6. Kemudahan Kredit yang Diharapkan

\begin{tabular}{|l|c|c|}
\hline \multicolumn{1}{|c|}{ Item } & Jumlah & $\%$ \\
\hline Plafond & 5 & 8,19 \\
\hline Tingkat Bunga & 34 & 55,73 \\
\hline Jangka Waktu & 8 & 13,11 \\
\hline Proses Pengajuan & 3 & 4,91 \\
\hline Lainnya & 11 & 18,03 \\
\hline & 61 & 100 \\
\hline
\end{tabular}

Tabel 7. Rata-rata Konsumen Yang Membeli Produk

\begin{tabular}{|l|c|c|}
\hline $\begin{array}{l}\text { Jumlah } \\
\text { Konsumen } \\
\text { (Orang) }\end{array}$ & Jumlah & \multicolumn{2}{l|}{} \\
\hline$<20$ & 7 & 11,47 \\
\hline $20-50$ & 22 & 36,06 \\
\hline $50-70$ & 6 & 9,83 \\
\hline $70-100$ & 9 & 14,75 \\
\hline$>100$ & 17 & 27,86 \\
\hline & 61 & 100 \\
\hline
\end{tabular}

Tabel 8. Penggunaan Tenaga Kerja

\begin{tabular}{|l|c|c|}
\hline \multicolumn{1}{|c|}{ Lama } & Jumlah & $\%$ \\
\hline$<5$ orang & 13 & 21,31 \\
\hline $5-10$ orang & 24 & 39,34 \\
\hline $10-20$ orang & 10 & 16,39 \\
\hline$>20$ orang & 14 & 22,95 \\
\hline & 61 & 100 \\
\hline
\end{tabular}

Tabel 9 Pendapat Pengusaha tentang Prediksi Kelangsungan Usahanya

\begin{tabular}{|l|c|c|}
\hline \multicolumn{1}{|c|}{ Lama } & Jumlah & $\%$ \\
\hline$<5$ th & 16 & 26,22 \\
\hline $5-10$ th & 19 & 31,14 \\
\hline$>10$ th & 15 & 24,59 \\
\hline Lainya & 11 & 18,03 \\
\hline & 61 & 100 \\
\hline
\end{tabular}


menggunakan tenaga kerja sejumlah 10 atau kurang, sekitar 16 persen menggunakan 1020 orang dan hanya sekitar 16 persen saja yang mampu menampung lebih dari 20 orang. Untuk meningkatkan skala usaha dan meningkatkan penggunaan tenaga kerja tentu dipengaruhi oleh banyak faktor yang meliputi pemasaran produk, kemampuan usaha dan investasi baru.
Beberapa informasi tersebut ternyata tidak membuat pengusaha pesimis. Sebagian besar dari mereka mengatakan bahwa prospek usaha masih baik, dan 90 persen dari mereka berminat mengembangkan usaha. Namun demikian, ada beberapa hal yang menjadi hambatan mereka. Hasil kajian tentang hambatan tersebut dipaparkan pada tabel 12. Namun hal

Tabel 10 Tingkat Persaingan Usaha

\begin{tabular}{|l|c|c|}
\hline Item & Jumlah & \% \\
\hline Sangat Ketat & 11 & 18,03 \\
\hline Ketat & 8 & 13,11 \\
\hline Cukup Ketat & 27 & 44,26 \\
\hline Kurang Ketat & 13 & 21,31 \\
\hline Sangat Longgar & 2 & 3,27 \\
\hline & 61 & 100 \\
\hline
\end{tabular}

Tabel 11. Pendapat Pengusaha Tentang Rencana Usaha

\begin{tabular}{|c|l|l|l|l|l|l|}
\hline \multirow{2}{*}{} & \multicolumn{2}{|l|}{ Prospek Baik? } & \multicolumn{2}{l|}{$\begin{array}{l}\text { Mengembangkan } \\
\text { Usaha? }\end{array}$} & \multicolumn{2}{l|}{$\begin{array}{l}\text { Ingin Pindah } \\
\text { Usaha? }\end{array}$} \\
\cline { 2 - 7 } & Ya & Tidak & Ya & Tidak & Ya & Tidak \\
\hline Jumlah & $\mathbf{4 9}$ & $\mathbf{1 2}$ & $\mathbf{5 5}$ & $\mathbf{6}$ & $\mathbf{1 4}$ & $\mathbf{4 7}$ \\
\hline$\%$ & 80,32 & 19,67 & 90,16 & $\mathbf{9 , 8 3}$ & 22,95 & 77,04 \\
\hline
\end{tabular}

Tabel 12. Pendapat Pengusaha Tentang Beberapa Alasanyang Tidak Mendukung Usaha

\begin{tabular}{|l|l|}
\hline 1 & Persaingan ketat \\
\hline 2 & Biaya operasional \& resiko tinggi \\
\hline 3 & Konflik dengan lingkungan ataupun pengusaha lain \\
\hline 4 & Konflik dnegan pemerintah pemerintah \\
\hline 5 & Lemahnya akses ke perbankan \\
\hline 6 & Pemasaran yang sukar \\
\hline 7 & Mahalnya biaya investasi \\
\hline 8 & Rendahnya komitmen pemerintah \\
\hline
\end{tabular}


penting yang perlu dikemukakan adalah perlunya regulasi dari pemerintah yang meliputi perbaikan sarana dan prasarana, akses perbankan dan perbaikan iklim ekonomi yang lebih baik.

\section{Penutup}

Dari kajian ini dapat disimpulkan bahwa usaha kecil dan menengah memiliki perananpenting dalam perekonomian nasional, khususnya dalam penyediaan lapangan kerja. Namun demikian, masih diperlukan regulasi pemerintah untuk meningkatkan kinerja UKM di Indonesia, khusunya untuk mengatasi beberapa hal yang menjadi hambatan mereka. Regulasi dari pemerintah yang diperlukan meliputi perbaikan sarana dan prasarana, akses perbankan dan perbaikan iklim ekonomi yang lebih baik untuk mendukung dan meningkatkan daya saing mereka serta meningkatkan jaminan kelangsungan usaha.

\section{Daftar Pustaka}

Ali, A. Dan Swiercz, P.M. (1991), "Firm Size and Export Behaviour: Lessons from the Midwest," Journal of Small Business Management, April.

Baswir, Revrisond, 1997, Agenda Ekonomi Kerakyatan, Pustaka Pelajar Offset, Juli 1997.

Chris Manning, Tadjuddin Noer Effendi, Penyunting, 1991, Urbanisasi, Pengangguran dan Sektor Informal di Kota, Jakarta:Yayasan Obor Indonesia.
Feriyanto, Nur, Jaka Sriyana, Awan S Dewanta dan Priyongo S, 2001, Gerakan Mengatasi Kemiskinan di Kota Yogyakarta, Laporan Riset, Kerjasama Pusat Riset EkonomiBappeda Kota Yogyakarta

ILO, 1991, The Dilemma of the Informal Sector. Report of the Director General, Part 1, the $78^{\text {th }}$ Session of the International Labour Conference, Geneva

Sarosa, Wicaksono, 2000, Pengantar: Menyoroti Sektor Informal Perkotaan," Research and Development Director Urban and Regional Development Institute (URDI) diakses pada 7 Agustus 2004 dari http:// www.urdi.org/urdi/bulletin/volume12a.php

Sethuraman., S.U., 1993, The Urban Informal Sector in Developing Countries, International Labor Organization, Jenewa

Tambunan, Tulus (1999), Perkembangan Industri Skala Kecil di Indonesia, Jakarta: PT Mutiara Sumber Widya.

Tambunan, Tulus (2003), Perkembangan UKM dalam Era AFTA: Peluang, Tantangan, Permasalahan dan Alternatif Solusinya. Paper Diskusi pada Yayasan indonesia Forum

Todaro., Michael P,2000, Economic Development, Sevent Edition, Massachusetts 